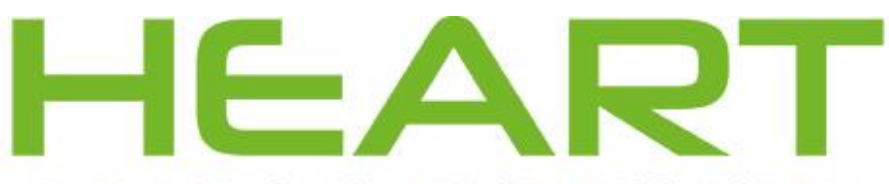

HEALTH \& EDUCATION ADVICE \& RESOURCE TEAM

\title{
Helpdesk Report: The teacher labour market in Pakistan
}

\section{Date: 9 September 2016}

Query: Produce a report:

1) Describing the existing evidence on Pakistan/South Asian teacher labour markets comparing teacher salaries against salaries in other sectors for individuals with similar levels of qualifications and experience.

2) Looking at the existing evidence on teachers in the low-fee private sector in Pakistan and in other contexts with thriving low fee sectors to answer: how segmented is the labour market? Who teaches in these schools? Why? Is the current wage paid to teachers in the low fee sector a market clearing wage?

3) Aim to discuss what the potential implications of a minimum wage legislation could be on teachers within the low-fee sector.

Purpose: To focus on the potential impact of a minimum wage legislation on teachers in the low fee sector in Pakistan.

\section{Contents}

1. Introduction

2. Methodology and quality of evidence

3. Evidence on the teacher labour market in South Asia

4. Evidence on teachers in the low-fee private sector

5. Is a minimum wage for teachers feasible and appropriate in Pakistan

6. Bibliography

7. Additional information

\section{Introduction}

This report undertakes a rapid review of existing literature and summarises some key evidence on the teacher labour market in South Asia. It specifically focuses on salaries and conditions of teachers in the low-fee private sector in contexts where these sectors are a significant part of the education system. In doing so, this review aims to help inform the development of DFID's policy position on the minimum wage legislation in Pakistan as it may pertain to teachers, specifically in the private schooling sector (specifically the low-fee sector and among other non-state actors).

\section{Definitional issues and caveats}

It is important to caveat some definitional and measurement concerns before synthesising existing research on these issues. Low-fee private schools (LFPS), sometimes also referred to as low-cost private schools (LCPS) - typically tend to encompass any 'market-oriented (nominally for profit) schools that are dependent on user fees for some or all of their running and development costs' (Mc Loughlin, 2013). As a result, these schools tend to not only have a degree of independence from the state but also rely on attracting and retaining pupils to 
ensure viable and successful business models. Moreover, they are distinct from elite private schools in that they typically charge fees that are deemed more affordable to families in lower socio-economic groups (ibid) and they tend to locate in rural areas and slums as well as in locations where low-income families reside. The broad 'low-fee private school' category encompasses an array of different types of providers:

a) With different motives: for example religious and philanthropic schools and NGO-run schools targeting specific communities or marginalised groups to purely private schools operating on for-profit business models and Public Private Partnership (PPP) arrangements where the government may heavily subsidise and regulate the school which makes the distinction between private and public education blurry.

b) Operating at varied scales: operated by single owner-operators to large international chains.

c) Targeting different clients including the rich as well as those from poorer backgrounds. There are further distinctions between types of LFPS - those that are officially 'recognised' by the state and the 'unrecognised' schools which operate 'off the radar' and are not regulated or recognised as even existing on government records.

There are further challenges in piecing together a comprehensive picture of the true nature and scale of private provision. For example, in India most existing data sets (such as ASER) collate private aided and private unaided schools into a single 'private' category and whilst for some states this distinction is unimportant, for others it is not. Furthermore, a major caveat in our understanding of the low-fee private sector is that despite knowing of its existence and the fact that it is increasingly catering to a large share of children in many parts of the world, the exact scale of low-fee private schools is not reliably documented. There are no consistent accounts of what exactly a 'low-fee private school' is, for example at what fee threshold is a school deemed to be 'low-fee' and catering specifically to a certain group of individuals. The evidence reviewed in this paper, therefore, is not based on a well-defined notion of a 'low fee private' school but encompasses literature on the private sector which may or may not include clear cut distinctions and definitions. These deficiencies in the data are also echoed by Srivastava et al. (2013) who highlight the paucity of comprehensive data on the proportion of recognised and unrecognised schools, distortions in existing data, no official definition of a 'low-fee private school' and difficulty making comparisons across existing data sets due to differences in operationalization with data such as ASER not distinguishing between aided and un-aided schools, in India.

\section{Private schools cater to large populations in many developing countries}

Nevertheless, there is now a large body of literature documenting the emergence and the role of the private sector - no matter how homogenously defined - in being a major player in providing education in many parts of the developing (and developed) world. This explosion in particular of for-profit schools in rural and poor settings has been documented in India, Pakistan, Ghana, Nigeria, Mozambique and Kenya among other settings by Tooley and Dixon (2005), Dixon (2012), Alderman, Orazem and Paterno (2001), Andrabi, Das \& Khwaja (2013), Aslam (2009) and several others. South Asia, and India and Pakistan specifically, have seen a tremendous rise in the private sector catering to rural populations.

This rise in private enrolments has been consistently documented by the Annual Status of Education Reports (ASER) since 2005 in India and since 2009 in Pakistan. To illustrate, consider the evidence from India's official District Information System on Education (DISE) data that show that over the short four year period from 2010-11 to 2014-15, enrolment in public schools fell by 11.3 million students and enrolment in private unaided schools rose by 18.5 million students. In some Indian states now, nearly $50 \%$ or more of the elementary school age children are attending private unaided schools. Evidence of a similar nature exists in Pakistan with the Annual Status of Education Reports (ASER) from various years continually showing high and increasing enrolments in 'private' and 'non-state' schools even in rural areas of the country. Overall, the share of the private primary education in Pakistan in 
2015 was 39 per cent (Carneiro, Das and Reis, 2016). The growth of private schools, especially the LFPS, is arguably most visible in Punjab and Khyber-Pakhtunkhwa provinces. For example, some argue that virtually all the gain in school participation in Punjab over the $2004 / 05$ and $2010 / 11$ period especially at the primary level is attributable to private schools (Aziz et al. 2014).

\section{Many poor parents are willing to pay for private schooling}

The growth of the private sector in so many parts of the world and especially in rural areas and urban slums has been arguably driven by discontent with the poor quality of state schooling provided. Even in environments where parents are poor and where they can access free government schooling, the evidence appears to suggest that they are willing to pay for private schooling. Other factors, such as reduced distance to school through accessing private schools also play an important role. A recent paper from rural Pakistan (Carneiro, Das and Reis, 2016.) strongly corroborates this finding. Using unique data from 112 rural education markets (villages) in Punjab, Pakistan with thriving private sectors resulting in significant choice between state and private schooling, the authors show that the existence of a low-fee private school market is greatly valued by households in their sample. Moreover, the authors find that families are willing to pay between $75 \%$ and $115 \%$ of the average annual private school fee for a 500 meter reduction in distance. In contrast, they find price elasticities to be low -0.5 for girls and 0.2 for boys, and the authors argue that this evidence on distance and price elasticities is at odds with the policy makers' belief that school fees deter enrolment and participation.

These small numbers suggest that very large increases in tuition fees would be required to induce large shifts away from the private sector (Carneiro et al, 2016, p. 26). Parental willingness to pay for private schooling for girls also stems from the predominant female teachers that are typically found in these schools. The authors of this study, for example, find that the elasticity of demand with respect to female teachers is positive for girls and negative for boys and on average girls' parents are willing to pay an additional \$2.8/year for an increase of 10 percentage points in the proportion of female teachers in the school, which corresponds to about $20 \%$ of average annual school fees in a private school (p. 30). This, the authors note, is a large amount and 'is consistent with the fact that the average proportion of female teachers is close to $90 \%$ in schools attended by girls.' (p. 31). Proximity of private schools, a conducive environment for female students, a client-focused business approach, better learning outcomes and parental preferences for fee-paying schools have also been cited as contributing to low cost private schools' competitive advantage according to a recent study in Pakistan (ILM IDEAS, 2014).

\section{Teacher salaries}

Teachers in South Asia are generally well paid not only when compared to the average person in the population but also when compared to similarly qualified individuals within the population. However, whilst teachers in the public sector tend to earn between 5-7 times as much (and sometimes far more) than the GDP/capita and comparable salaries to similar professionals in other occupations, teachers in the private sector earn far less. More specifically, teachers in the low-fee sector earn up to a tenth (and even more) of their government school counterparts. Such gaps are reported in India, Pakistan, the Dominican Republic, Tanzania, Thailand, Mozambique and several other countries. With public sector salaries growing even more in recent years due to revisions in Basic Pay Scales and through union demands, these gaps between government and private sector salaries are likely to have widened further. However, raw comparisons of teacher wages are confounded by the differences in characteristics observed between teachers in the two sectors; teachers in the government sector are more qualified, have received more training and have more experience. However, even after controlling for these observed differences between 
teachers, much of the wage gap between private and government school teachers remains unexplained (Andrabi et al. 2008).

The low salary paid to teachers within the low-fee sector is an important condition for the viability of their business model. As teacher salaries constitute a large proportion of the total costs of running schools in South Asia, charging low fees from pupils is contingent on paying staff less. These wages, often well below the minimum wage, are market clearing wages that reflect the dynamics of the market and the existing demand and supply conditions. Whilst there is evidence of low morale and dissatisfaction amongst teachers in the low-fee sector, limited outside options available to those working within it means that they often continue to remain employed within these schools unless faced with better employment opportunities or changed conditions (such as getting married).

\section{Summary conclusions}

The feasibility of imposing a broad-based minimum wage legislation for teachers, especially those working in the low-fee sector within the Pakistani context is questioned by this study. Firstly, the scale of the private school sector - specifically the low-fee variety with most schools likely to be unregistered and unrecognised and hence not even existing on government books - is not known. This, in turn, raises the question of how such legislation will actually be implemented. Secondly, one needs to consider the impact of such legislation on the operations of small-scale informal low-fee enterprises which rely on charging low fees by paying low salaries. One implication of such legislation would be that it may expose these low-fee schools to further illegality and corruption when faced with the prospect of meeting a government mandate that they cannot fulfil or, worse still, cause large scale closures.

It is important that the government effectively regulate the functioning of these enterprises but effective regulation should be based on the realities of all kinds of providers which now exist in Pakistan rather than on the elite and larger urban private schools alone. The implications of legislation and ordinances on the diverse range of providers need to be carefully considered but this is typically not the case. This is usually partly due to a lack of understanding about the true nature of the private sector with education legislation being framed with the more 'visible' urban high-fee charging private schools rather than being mindful of the diversity of private schools at varying fee levels. The need for further research in gaining a better and more comprehensive understanding of low-fee schools is vehemently echoed by Srivastava (2013) who notes that our initial understanding of this sector is, at best, 'tentative' and should, therefore, be treated with caution (p. 28).

\section{Methodology and quality of evidence}

\section{Methodology}

This review is based on a quick scoping of published and unpublished research on the teacher labour force in the South Asia setting as well as in some other contexts where the low-fee private sector and non-state sectors are known to be prevalent. Evidence was scoped from a range of sources including published papers in peer reviewed journals as well as from reports and documents from agencies and organisational websites and through direct requests from authors known to be working on these issues. Wherever possible, we aim to highlight evidence on Pakistan. However, where evidence is available from other contexts where the low-fee sector is prevalent, it is discussed to provide comparisons.

\section{Quality of evidence}


As noted before, despite intense interest in the private sector, there is limited research on the scale of the private sector in many parts of the world. Pakistan is no exception. A lack of knowledge about the true nature and extent of private provision and enrolments at different education levels results in educational legislation and policy for private schools being made under the disadvantage of serious knowledge gaps. For example, there is scattered information on the fee/costs/teacher salaries of private schools and the value for money they offer, or on the effect of chains of private schools; and there is no evidence on teacher unionisation in, and the political economy of, the private education sector, as well as its system-wide effects (Day Ashley et al. 2014). In Pakistan, most of the evidence on low-fee schools is based on research funded by the World Bank based on the LEAPS data set from villages in rural Punjab. These data, longitudinal in nature, are rich and able to robustly answer very specific questions. However, these findings are not generalisable to other contexts even within the country. Other, more recent research is also not generalisable and work by Aslam and Kingdon (2011), though highlighting some very important features of teachers within the two sectors, is limited to only Lahore district. There are some recent reports on the low-fee sector (specifically those funded by DFID) that address the access to finance for low-fee schools using a sample across 3 provinces but, yet again, the findings are not generalizable across these provinces.

The analysis undertaken in this study, therefore, collates a wide range and quality of evidence from Pakistan and from other contexts to provide answers to the specific questions posed. In particular, the study highlights the need for more research on the nature and role of private schools in Pakistan and elsewhere, focusing specifically on identifying all types of private schools rather than collating them into one homogenous category. It is also important to highlight that research in this area could significantly benefit from a multi-disciplinary lens that focuses at the extent to which educational legislation and policies impact different providers and specifically the low-fee variety. In doing so, it is also important to understand how specific policies and interventions that have been aimed and designed to deliver quality education specifically with regards to the private sector interact with contextual dynamics and with what impact.

\section{Evidence on the teacher labour market in South Asia}

This section discusses existing evidence on the teacher labour market in South Asia. The section focusing on salaries is based on literature that has used Labour Force Surveys (LFS) and secondary data from different contexts within South Asia to document teacher salaries without necessarily being able to differentiate between teachers in government and private sectors (let alone disaggregate further to teachers within low-fee schools).

Incentives offered to teachers will clearly affect their attitudes and ultimately how effective they are and the structure of teacher salaries, therefore, has the potential to significantly impact teacher effort and ultimately student outcomes. This is especially important in South Asia where up to $90 \%$ of government education budgets are spent on recurrent salary expenses of civil service teachers (Dundar et al. 2014, p. 2091). How well are teachers, regardless of sector of employment, paid within the South Asia region?

1 The background paper containing all the teacher wage analysis for this book chapter was prepared by Aslam, Rawal and Kingdon (2014). 
A World Bank book (Dundar et al. 2014) benchmarks teacher salaries in several ways in an attempt to answer this question:

1) In the first instance, it compares teacher wages by computing the ratio of teacher salaries as a proportion of a country's per capita gross domestic product (GDP or income) and comparing it within the region and with other countries. This ratio allows us to identify how affluent (or poor) teachers are with respect to an average person in a given country. It is also a measure of the economic and social distance between the teachers and the student with a larger 'distance' hinting at a potential barrier to teaching.

2) Alternatively, it compares teacher salaries to those of similarly qualified individuals in other occupations in the labour market.

As already mentioned, it should be noted that these benchmarking exercises are done without differentiating between the two distinct teacher labour markets experienced by teachers in the government and in the private sectors.

\section{'Teachers' in South Asia are relatively well paid}

The tables below (Table 1 and 2) indicate that whilst there is significant heterogeneity in teacher salaries (for all teachers regardless of whether they are in private or government sector jobs and across all education levels) across the region, on average, teachers are better off than the average person in both Bangladesh (teacher salary is twice as much as per capita GDP in 2002) and in Pakistan (ratio of 5.2). These compare with ratios of 3 is to 1 for Asian countries and for 2 is to 1 for OECD countries (Mingat 2002).

Table 1: Ratio of teacher salary to per capita income (Takas) by Division, Bangladesh

\begin{tabular}{|c|c|c|c|c|}
\hline Division & $\begin{array}{c}\text { 1999-2000 per } \\
\text { capita GDP at } \\
\text { constant (1995-96) } \\
\text { prices (Tk) } \\
\text { (a) }\end{array}$ & $\begin{array}{l}\text { Inflated 1999- } \\
2000 \text { per capita } \\
\text { GDP to } 2002 \\
\text { prices }^{\mathrm{a}}(\mathrm{Tk}) \\
\text { (b) }\end{array}$ & $\begin{array}{l}\text { Annual teacher } \\
\text { salaries in } 2002^{\mathrm{b}} \\
\text { (Tk) } \\
\text { (C) }\end{array}$ & $\begin{array}{l}\text { Teacher salary as } \\
\text { multiple of per } \\
\text { capita GDP in } 2002 \\
\text { (d) }\end{array}$ \\
\hline Barisal & 13,343 & 17,381 & 40,745 & 2.3 \\
\hline Chittagong & 15,715 & 20,470 & 39,001 & 1.9 \\
\hline Dhaka & 19,308 & 25,151 & 38,672 & 1.5 \\
\hline Khulna & 15,464 & 20,143 & 39,665 & 2.0 \\
\hline Rajshahi & 13,091 & 17,052 & 43,437 & 2.5 \\
\hline Sylhet & 12,591 & 16,401 & 39,460 & 2.4 \\
\hline Bangladesh & 15,791 & 20,569 & 40,163 & 2.0 \\
\hline
\end{tabular}

Source: Statistical Yearbook of Bangladesh 2005.

Note: GDP = gross domestic product.

a. Column (b) shows column (a) flgures Inflated to 2002 prices using the Consumer Price Index (General), Statistical Yearbook of Bangladesh (2008). Teachers were Identifled from the 2002 Bangladesh Labour Force Survey (LFS 2002) using the 3-diglt occupation codes.

b. The reported salarles are for all teachers at all levels in government and private school jobs.

Source: Dundar et al. (2014), Table 5.5 (p.210). 
Table 2: Ratio of teacher salary to per capita income (Rupees), by province, Pakistan

\begin{tabular}{|c|c|c|c|c|c|c|c|}
\hline Province & $\begin{array}{c}\text { Average } \\
\text { monthly } \\
\text { household } \\
\text { income } \\
\text { (2004-05), } \\
\text { (PRe)/ } \\
\text { month } \\
\text { (a) }\end{array}$ & $\begin{array}{c}\text { Average } \\
\text { household } \\
\text { size }(1998 \\
\text { census) }^{\mathrm{a}} \\
\text { (b) }\end{array}$ & $\begin{array}{l}\text { Estimated } \\
\text { monthly } \\
\text { per capita } \\
\text { income } \\
\text { (PRe) } \\
\text { (c) }\end{array}$ & $\begin{array}{l}\text { Annual } \\
\text { per capita } \\
\text { income } \\
\text { (d) }\end{array}$ & $\begin{array}{c}\text { Annual } \\
\text { teacher } \\
\text { salaries in } \\
2008^{b} \\
\text { (PRe) } \\
\text { (e) }\end{array}$ & $\begin{array}{c}\text { Annual } \\
\text { per } \\
\text { capita } \\
\text { income } \\
\text { in } 2008 \\
\text { prices }^{c} \\
\text { (PRe) } \\
\text { (f) }\end{array}$ & $\begin{array}{c}\text { Teacher } \\
\text { salary as } \\
\text { multiple of } \\
\text { per capita } \\
\text { income in } \\
2008 \\
\text { (g) }\end{array}$ \\
\hline Punjab & 9,488 & 7.0 & 1,355 & 16,265 & 115,172 & 22,283 & 5.2 \\
\hline Sindh & 10,413 & 6.1 & 1,707 & 20,485 & 128,624 & 28,064 & 4.6 \\
\hline NWFP & 9,395 & 8.0 & 1,174 & 14,093 & 106,572 & 19307 & 5.5 \\
\hline Balochistan & 8,849 & 6.8 & 1,301 & 15,616 & 127,070 & 21,394 & 5.9 \\
\hline Pakistan & 9,685 & 6.9 & 1,404 & 16,844 & 119,480 & 23,076 & 5.2 \\
\hline
\end{tabular}

Source: Pakistan Statistical Yearbook 2007.

Note: Teachers were Identifled using the occupation codes In Pakistan Labour Force Survey (2008). NWFP = North-West Frontler Province.

a. Pakistan Statistical Yearbook (2007).

b. The reported salarles are for all teachers in government and private school jobs teaching at all levels.

c Column (f) shows column (d) figures inflated to 2008 prices using the Wholesale Price Index reported in Pakistan Statistical Yearbook (2007).

Source: Dundar et al. (2014), Table 5.6 (p.210).

Table 3: Ratio if teacher salary to per capita income (rupees), by state, India

\begin{tabular}{|c|c|c|c|c|}
\hline State & $\begin{array}{l}\text { Per capita net domestic } \\
\text { product at factor cost } \\
\text { (base }=1999-2000) \\
\text { (a) }\end{array}$ & $\begin{array}{c}\text { Per capita net } \\
\text { domestic product in } \\
2008 \text { prices }^{\mathrm{a}} \\
\text { (b) }\end{array}$ & $\begin{array}{l}\text { Annual teacher } \\
\text { salaries in } 2008^{\mathrm{b}} \\
\text { (c) }\end{array}$ & $\begin{array}{l}\text { Teacher salary as } \\
\text { multiple of per } \\
\text { capita income } \\
\text { (d) }\end{array}$ \\
\hline Andhra Pradesh & 27,362 & 42,958 & 89,876 & 2.1 \\
\hline Assam & 16,272 & 25,547 & 127,853 & 5.0 \\
\hline Bihar & 10,206 & 16,023 & 187,685 & 11.7 \\
\hline Jharkhand & 16,294 & 25,582 & 124,290 & 4.9 \\
\hline Gujarat & - & - & 123,862 & - \\
\hline Haryana & 41,896 & 65,777 & 148,944 & 2.3 \\
\hline Himachal Pradesh & 32,343 & 50,779 & 124,982 & 2.5 \\
\hline Jammu and Kashmir & - & - & 103,415 & - \\
\hline Karnataka & 27,385 & 42,994 & 110,681 & 2.6 \\
\hline Kerala & 35,475 & 55,696 & 126,593 & 2.3 \\
\hline Madhya Pradesh & - & - & 157,147 & - \\
\hline Chhattisgarh & 19,521 & 30,648 & 124,383 & 4.1 \\
\hline Maharashtra & - & - & 107,886 & - \\
\hline Odisha & 18,212 & 28,593 & 207,023 & 7.2 \\
\hline Punjab & 33,198 & 52,121 & 149,073 & 2.9 \\
\hline Rajasthan & 19,708 & 30,942 & 166,609 & 5.4 \\
\hline Tamil Nadu & 30,652 & 48,124 & 96,034 & 2.0 \\
\hline Uttar Pradesh & 12,481 & 19,595 & 103,396 & 5.3 \\
\hline Uttarakhand & 25,114 & 39,429 & 170,831 & 4.3 \\
\hline West Bengal & 24,720 & 38,810 & 108,534 & 2.8 \\
\hline Simple means for states & 23,642 & 37,119 & 11,9540 & 4.2 \\
\hline
\end{tabular}

Source: Reserve Bank of Indla: Handbook of Statistics on Indlan Economy, http://wwwsbl.org.In/scripts/AnnualPublications aspx:head=Handbook\%20 of\% 205tatistics\%200n\%20indlan\%20Economy.

Note: $-=$ not avallable.

a. Colurnn (b) shows column (a) figures inflated to 2008 prices using the All Indla Consumer Price Index (General) for Industrlal workers. b. Teachers were Identifled using the National Sample Survey (NSS) 2008 3-diglt occupation codes. It is not possible to sort regular from para-teachers in NSS data because occupation codes do not distingulsh between the two teacher types. The reported salarles are for regular and para-teachers in government and private school jobs.

Source: Dundar et al. (2014), Table Annex 5A (p.232). 
Additional evidence from India (Table 3) also paints a similar story - whilst there is heterogeneity across states (with teacher salaries as a multiple of per capita GDP as high as 11.7 in Bihar), on average across the Indian states teacher salaries are more than 4 times as high as per capita GDP. A teacher in India is 4 times as better off than the average person.

Benchmarking using the second technique, i.e. comparing teacher salaries with those of 'similar' individuals in other occupations also indicates that whilst teachers are paid similar to other occupations in Bangladesh, teacher salaries (within both government and private sectors and across all education levels) are better than those in other occupations (Tables 4 and 5 illustrate the cases of Pakistan and Sri Lanka).

Table 4: Teacher pay relative to other occupations, Pakistan

\begin{tabular}{|c|c|c|c|c|}
\hline \multirow[b]{2}{*}{ Pakistan } & \multicolumn{2}{|c|}{2000} & \multicolumn{2}{|c|}{2008} \\
\hline & $\begin{array}{c}\text { Mean monthly } \\
\text { salary (US\$) }\end{array}$ & $\begin{array}{l}\text { Ratio of teacher } \\
\text { salary to other } \\
\text { salaries }\end{array}$ & $\begin{array}{c}\text { Mean monthly } \\
\text { salary } \\
\text { (in 2005 PPP USS) }\end{array}$ & $\begin{array}{c}\text { Ratio of teacher } \\
\text { salary to other } \\
\text { salaries }\end{array}$ \\
\hline Teachers & 230 & - & 303 & - \\
\hline Legislators & 351 & 0.7 & 384 & 0.8 \\
\hline Professionals & 314 & 0.7 & 360 & 0.8 \\
\hline Associate professionals & 253 & 0.9 & 303 & 1.0 \\
\hline Clerks & 239 & 1.0 & 300 & 1.0 \\
\hline Service workers/shops & 221 & 1.0 & 239 & 1.3 \\
\hline Skilled agriculture & 170 & 1.4 & 234 & 1.3 \\
\hline Crafts & 215 & 1.1 & 242 & 1.3 \\
\hline Plant/machine operators & 251 & 0.9 & 227 & 1.3 \\
\hline Elementary & 172 & 1.3 & 179 & 1.7 \\
\hline $\begin{array}{l}\text { All nonteachers (weighted } \\
\text { average) }\end{array}$ & 257 & 0.9 & 277 & 1.1 \\
\hline
\end{tabular}

Source: Data from Pakistan Labour Force Survey 2000 and 2008.

Note: Teachers were identffled using occupation codes. Although they are often classifled within the broader "Professionals" and "Assoclate Professionals" categorles in survey data, 2-and 3-digit occupation codes within these categorles help identify teachers, who were separately coded as "Teachers" by generating a new occupation code and excluding them from

"Professionals" and "Assoclate Professionals" to prevent double counting. Salary estirnates are for all Individuals ages 18 years or above workIng as wage earners and reporting at least 10 years of schooling. Total Income (deflated to 2005 purchasing power parity [PPP] dollars) reportedly earned from all jobs in the past month is used for the salary estimate. — = not avallable.

Source: Dundar et al. (2014), Table Annex 5.8 (p.212). 


\begin{tabular}{|c|c|c|c|c|}
\hline Tea & pay & relative & other & occupations, \\
\hline \multirow[b]{2}{*}{ SriLanka } & \multicolumn{2}{|c|}{2000} & \multicolumn{2}{|c|}{2008} \\
\hline & $\begin{array}{c}\text { Mean monthly } \\
\text { salary (US\$) }\end{array}$ & $\begin{array}{l}\text { Ratio of teacher } \\
\text { salary to other } \\
\text { salaries }\end{array}$ & $\begin{array}{l}\text { Mean monthly } \\
\text { salary, 2005 } \\
\text { (USS PPP) }\end{array}$ & $\begin{array}{c}\text { Ratio of teacher } \\
\text { salary to other } \\
\text { salaries }\end{array}$ \\
\hline Teachers & 242 & - & 280 & - \\
\hline Legislators & 257 & 0.9 & 249 & 1.1 \\
\hline Professionals & 258 & 0.9 & 281 & 1.0 \\
\hline Associate professionals & 238 & 1.0 & 250 & 1.1 \\
\hline Clerks & 219 & 1.1 & 212 & 1.3 \\
\hline Service workers/shops & 211 & 1.1 & 187 & 1.5 \\
\hline Skilled agriculture & 121 & 2.0 & 117 & 2.4 \\
\hline Crafts & 163 & 1.5 & 156 & 1.8 \\
\hline Plant/machine operators & 180 & 1.3 & 178 & 1.6 \\
\hline Elementary & 158 & 1.5 & 133 & 2.0 \\
\hline Armed forces & 296 & 0.8 & 315 & 0.9 \\
\hline Other & 151 & 1.6 & 170 & 1.6 \\
\hline $\begin{array}{l}\text { All nonteachers } \\
\text { (weighted average) }\end{array}$ & 216 & 1.1 & 191 & 1.5 \\
\hline
\end{tabular}

Source: Data from the Sri Lanka Labour Force Survey 2000 and 2008.

Note: See note under table 5.8. - = not avallable; $\mathrm{PPP}=$ purchasing power parity.

Source: Dundar et al. (2014), Table Annex 5.9 (p.212).

Dundar et al. (2014) further document a relatively advantageous position of teachers across countries in South Asia where teachers work significantly fewer hours than individuals in other occupations and earn significantly higher hourly salaries than other 'similar' individuals. Moreover, contrary to common perception, the study demonstrates how teacher salaries have tended to rise significantly over time with some of the largest increases in real terms (adjusting for the Cost Price Index) being seen in teacher salaries in Nepal, Pakistan and Sri Lanka between 2000 and 2008. Aslam and Rawal (2015) report similar findings as do Aslam et al. (2016).

\section{Evidence on teachers in the low-fee private sector}

\section{Teachers in the public and private sectors face different labour markets}

As mentioned before, the analysis on teacher salaries discussed in the previous section was unable to differentiate between teachers in the government and private sectors. However, with the emergence of the private sector as a major player across many parts of South Asia and given the heterogeneity within the private sector, it is very important to differentiate between teachers within the two sectors (and further) as they typically face a completely different set of incentives and work environments with resultant implications for student outcomes.

More general evidence on the segmentation within private and public sectors from within Pakistan suggests that the Pakistani labour market is characterised by very large wage gaps between public and private sector workers (Aslam and Kingdon, 2009). In 2004-2005, men in government jobs earned on average Rs.8211/month (\$137)1 and in private jobs only Rs.5420 $(\$ 90)$, a private:public ratio of $1: 1.5$. This raw public-private wage difference is even higher for women, the private:public wage ratio being 1:3, i.e. Rs.6614/month $(\$ 110)$ in public jobs and Rs.2160/month (\$36) in private sector jobs. This particular study goes on to show that the large raw gaps in public and private sector earnings persist for both males and females even after conditioning on observed characteristics (such as education levels, experience, 
and province and region fixed-effects). The study also shows the public-private wage gap to be much larger for women than for men signifying labour market differentiation to be far greater for women across the two sectors.

In terms of how teacher salaries are determined across the two sectors, there are very clear differences. Whilst the civil service teacher salaries are based on basic pay scales and reward experience and tenure, the private sector determines a market clearing wage (see below). This is the case across labour markets in South Asia as well as in parts of Africa where the private sector has emerged as an important player in the education market. The teacher labour market characteristics are also different across the two sectors - for example, a significantly larger percentage of women are typically observed to be teaching within the private sector as compared to the government sector in South Asia. As an illustration, consider some demographic features of the teacher labour market in Pakistan (see Box 1 below). The labour market for teachers across the two sectors (state and private) looks similar across other parts of the region as well (for example, India).

\section{Box 1: Teacher labour market characteristics: illustrative example from Pakistan}

According to ISAPS (2010), the number of teachers in the private sector institutions is large and this reflects the large private sector within the country. Whist there were 0.3 million teachers in private educational institutions in 1999-2000 according to this report, this figure had doubled by $2007-2008$ (see table below) - with $44 \%$ of the 1.4 million teachers working in the private sector in 2008.

The number of female teachers in private educational institutions is also twice the number of male teachers ( $74 \%$ versus $26 \%$ across all education levels). The public sector teaching cadre looks different - in Punjab province, for example, according to 2012-2013 estimates reported in Alif Ailaan (2015), among the 327,307 public school teachers, $47 \%$ were female.

Table: Number of teachers in private schools (2000-2008), Pakistan

\begin{tabular}{|c|c|c|c|c|c|c|c|}
\hline S.No. & Level & Sex & $1999-2000$ & 2005 & $2007-08$ & $\begin{array}{c}\% \text { of Total } \\
\text { in } 2007-08\end{array}$ & $\begin{array}{l}\text { Change } \\
\text { since } \\
2000(\%)\end{array}$ \\
\hline \multirow{3}{*}{1} & \multirow{3}{*}{ Primary } & Male & 17,020 & 18,846 & 19,338 & $22 \%$ & $14 \%$ \\
\hline & & Female & 58,904 & 67,605 & 68,857 & $78 \%$ & $17 \%$ \\
\hline & & Total & 75,924 & 86,451 & 88,195 & $100 \%$ & $16 \%$ \\
\hline \multirow{3}{*}{2} & \multirow{3}{*}{ Middle } & Male & 28,752 & 48,583 & 49,888 & $25 \%$ & $74 \%$ \\
\hline & & Female & 77,629 & 145,661 & 149,371 & $75 \%$ & $92 \%$ \\
\hline & & Total & 106,381 & 194,244 & 199,259 & $100 \%$ & $87 \%$ \\
\hline \multirow{3}{*}{3} & \multirow{3}{*}{ High } & Male & 27,150 & 54,420 & 55,021 & $28 \%$ & $103 \%$ \\
\hline & & Female & 67,459 & 139,852 & 144,072 & $72 \%$ & $114 \%$ \\
\hline & & Total & 94,609 & 194,272 & 199,093 & $100 \%$ & $110 \%$ \\
\hline \multirow{3}{*}{4} & \multirow{3}{*}{ Total (1-3) } & Male & 72,922 & 121,849 & 124,247 & $26 \%$ & $70 \%$ \\
\hline & & Female & 203,992 & 353,118 & 362,300 & $74 \%$ & $78 \%$ \\
\hline & & Total & 276,914 & 474,967 & 486,547 & $100 \%$ & $76 \%$ \\
\hline \multirow{3}{*}{5} & \multirow{3}{*}{ Total $^{*}$} & Male & 81,264 & 182,912 & 191,854 & $32 \%$ & $136 \%$ \\
\hline & & Female & 213,638 & 390,661 & 405,764 & $68 \%$ & $90 \%$ \\
\hline & & Total & 294,902 & 573,573 & 597,618 & $100 \%$ & $103 \%$ \\
\hline & * (5) includer & $\begin{array}{l}\text { tival inst } \\
\text { the Ing-2 }\end{array}$ & 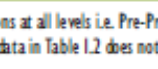 & $\begin{array}{l}\text { W. Higher Second } \\
\text { er teachers of Pre }\end{array}$ & $\begin{array}{l}\text { gree level, tedo } \\
\text { ry and Deena Ma }\end{array}$ & 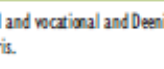 & laris \\
\hline & Corpilad by 1-Spps & Us of Prinate $E$ : & al Instittiox 1999 & 00 , Mational Edoca & Cerses 2005 and ME & 115 report for 2000 an & $007-08$ \\
\hline
\end{tabular}

Source: ISAPS, 2010, Table 1.2, p. 6. 
Evidence from rural Pakistan discussed in the LEAPS report (Andrabi et al. 2008) also suggests that in rural markets in the low-fee private schools, teachers are predominantly young, unmarried females - for example, in their sample from rural Punjab, the authors find $76 \%$ of teachers in private schools to be female (as compared to $57 \%$ in government schools), have a median age of 21 (as opposed to 40 in government schools), are typically unmarried (82\% females unmarried in private schools are opposed to $14.8 \%$ in rural government schools) and typically reside in the same village where they teach (56\% female teachers in private schools as opposed to only $19 \%$ in rural government schools in the sample).

The demographic profiles of teachers in government and private schools are also different in terms of qualifications, experience and training - teachers in government schools are better qualified, have received training and are more experienced as compared to their private school counterparts (see LEAPS 2008, Aslam and Kingdon 2011 and ILM IDEAS 2014).

Civil service teachers are politically active and propagate non-benevolent agendas, private school teachers are typically not organised

Other studies have similarly documented large increases in the salaries of civil service teachers in different parts of South Asia. The salary of regular teachers in government schools in Indian states, for example, is documented to have gone up manifold and in some states by as much as $100 \%$. This is largely the result of a reform aimed at increasing the take-home pay of teachers under the 'Sixth Pay Commission'. Under this reform, whilst pay increases were agreed in late 2008, they were applied retrospectively from $1^{\text {st }}$ January 2006. Kingdon (2010) shows that after the implementation of the 6th Pay Commission, salaries of regular primary school teachers in Uttar Pradesh increased by 115 percent, 101 percent increase for high school teachers and 103 percent increase for senior secondary school principals. Similar findings are reported by Jain and Dholakia (2009) who show the increase in salaries to be close to 285 percent in 2006 with a further increase by 200 percent in 2011. This gap in teacher earnings and the earnings of the rest of the population has had a major negative consequence of increasing the economic and social distance between teachers and students particularly as many teachers belong to upper social groups/castes whilst the pupils they teach tend to come from disadvantaged backgrounds. This social distance can generate prejudices to the detriment of the learning outcomes for the students (Rawal and Kingdon 2010).

There is evidence that civil service teachers have played a crucial role in propagating the agenda of demanding salary increases. There is now emerging evidence from the South Asia region that documents a strong political presence of civil service teachers who are well organised into associations and unions and well entrenched in the political arena to be able to influence key educational agenda items. Evidence also suggests that teachers tend to present less benevolent agenda items such as demanding salary increases and lessened work-loads rather than more altruistic demands that may benefit students (Aslam et al. 2016). According to a recent report on teacher unions in Pakistan, one of the key role teachers' organizations have played in recent years is in waging successful campaigns for the betterment of their own salaries (Alif Ailaan, 2015). The government of Pakistan has diligently revised government (and teacher) salary scales in the country. These salary revisions have successfully occurred in 1981, 1983, 1991, 1994, 2001, 2004, 2008 \& in $2011^{2}$ etc. Since then, there have been further revisions in the basic pay scale (BSP) of all government sector employees, including teachers ${ }^{3}$. Table 6 shows that over a three year period (2008-2011),

$2 \mathrm{http} / / /$ unesco.org.pk/education/documents/2014/publications/Status of Teachers in Pakistan.pdf 3 http://www.itechsoul.com/government-employees-new-revised-pay-scale-2015-bps-budget-2015-16 
government teacher salaries (basic pay) were revised by about $40 \%$. According to the Alif Ailaan report (2015), all teacher organisations have tended to converge around some core issues, with salary increase often being one of the most prominent and persistent demands.

Table 6: Basic Pay Scale revisions for Teachers, 2008-2011, Pakistan

\begin{tabular}{|c|c|c|c|c|c|c|c|}
\hline \multirow{2}{*}{ Teacher type } & & \multicolumn{6}{|c|}{ Basic Pay Scale (not including benefits and allowances) } \\
\hline & & \multirow{2}{*}{\multicolumn{2}{|c|}{$\begin{array}{c}2008 \\
\text { (Rs./month) }\end{array}$}} & \multirow{2}{*}{\multicolumn{2}{|c|}{$\begin{array}{c}2011 \\
\text { (Rs./month) }\end{array}$}} & \multirow{2}{*}{\multicolumn{2}{|c|}{$\%$ change over 3 years }} \\
\hline & & & & & & & \\
\hline & & Min & Max & Min & Max & Min & Max \\
\hline & & Salary & Salary & & & & \\
\hline \multicolumn{2}{|c|}{ Primary School Teacher } & 3820 & 10720 & 6200 & 17600 & 38 & 39 \\
\hline Elementary & School & 4920 & 16320 & 8000 & 26300 & 39 & 38 \\
\hline \multicolumn{8}{|l|}{ Teacher } \\
\hline Secondary & School & 6060 & 20160 & 10000 & 34000 & 39 & 41 \\
\hline \multicolumn{8}{|l|}{ Teacher } \\
\hline Head Teacher & & 9850 & 24650 & 16000 & 40000 & 38 & 38 \\
\hline
\end{tabular}

Source: Adapted from UNESCO (2013)4, Table 4.1, cited in Aslam et al. (2016).

However, this is in sharp contrast to private school teachers who are not organised into formal associations and typically do not have a voice (Alif Ailaan 2015). Similar findings have been observed in other parts of the developing world - Harma (2015) notes that teachers in low-fee private schools '....are not unionised and so do not engage in collective bargaining.' (p. 182). There is also evidence that civil service teachers have resisted education privatisation in Pakistan (see Box 2 below).

\section{Box 2: Education privatisation resisted in Pakistan by civil service teachers}

Aslam et al. (2016) state:

'In Pakistan, teacher organizations have also vehemently and almost unanimously opposed the privatization of education. Teachers have tended to view with extreme suspicion the mushrooming of private schooling across the country and the support the government has provided to the meteoric rise of the private sector. Teachers have argued that this has resulted in low and often unqualified entrants entering the profession, lowering its status and given the government the opportunity to revise the terms of government teacher contracts (by offering temporary contracts, or linking performance to pay) or even more drastically with government schools being offered for example to the Punjab Education Foundation (PEF) under a Public-Private-Partnership scheme which demotivates them and puts their jobs at risk. Teachers have resisted these changes by repeatedly striking and lobbying, with several strike actions reported in 2016: on 1 February, 2016, a demonstration was held in Rawalpindi led by the Punjab Teachers' Union (PTU)5, followed by several others (including one in Layyah, Sindh, on 17 January, 2016)6. At the time of writing this report, a newspaper article (dated 22 March, 2016) cited teacher unrest in Punjab over this issue and in particular with the provincial education department's circular handing over 145 government primary schools

4 http://unesco.org.pk/education/documents/2014/publications/Status of Teachers in Pakistan.pdf

5 http://www.teachersolidarity.com/blog/teachers-in-pakistan-fighting-schools-privatisation

6 http://nation.com.pk/national/17-Jan-2016/teachers-up-against-schools-privatisation 
in Rawalpindi district to PEF and the government 'relieving 590 teachers of the privatized schools and (handing) over their services to the executive district office, education (and) to 'adjust them in other schools". Teacher unions have 'warned' the government of Punjab that they will resist this move vehemently and wage resistance by demonstrating and 'taking to the streets. ${ }^{7}$

Source: Aslam et al. (2016).

Private schools pay low wages to their employees (typically women) and this is a necessary condition for the viability of the low-fee school model

Most low-fee private schools are informal enterprises and the viability of their business model requires meeting certain critical conditions. In particular, paying a low wage, sometimes a pittance, to their employees, is a necessary condition for the viability of a low-fee private schooling model (Andrabi et al. 2008, Fennell, 2013). In many contexts, low-fee private schools are small-scale operations owned by private individuals (a recent study by Härmä, 2016, for example notes that $87 \%$ of low-fee schools in her sample in Abuja, Nigeria are owned by private individuals suggesting that in this context of low-income settings, the lowfee private school model is of an individual entrepreneur-owned-low-fee school). Similar findings are reported from Pakistan - ILM IDEAS (2014) in their study of 305 (what they term low cost) private schools across primary, middle and secondary levels in Punjab, Sindh and Khyber Pakhtunkhwa (with fees ranging from Rs.300-Rs. 2000/month) found that $63 \%$ of these schools were unregistered and owned by sole-proprietors.

These small enterprises typically also charge low fees. Andrabi et al. (2008) show that the median annual fee in a rural private school in Pakistan in 2000 was Rs.600 and this, they argue, suggests that the monthly fee was typically less than the daily wage of an unskilled wage worker. Moreover, their study shows that the fixed costs of running low-fee schools are typically low, with the largest share (up to $90 \%$ ) of the schools' operational costs constituting teacher wages. A typical low-fee school in rural Pakistan employed 4 teachers, mostly locally resident women with at least a secondary education and enrolled about 100 children (cited in Andrabi et al. 2013). However, despite charging apparently low fees, low-income families may struggle to meet the expenses on a regular basis. For example, Härmä (2016a), in her study of low-income contexts within Abuja, also notes that even when schools are charging apparently low fees, many parents find it difficult to pay fees and schools report 'bad debts'. A large percentage (62\%) of proprietors in her sample also suggested that parents are irregular in paying fees. Resultant cash flow problems mean that school proprietors also have difficulty paying teacher salaries. Some of these findings have been reported by other researchers and in other contexts (Srivastava 2006. Adelabu and Rose 2004, Härmä and Adefisayo 2013, Schirmer 2010). Such constraints add to the financial woes of such enterprises. ILM IDEAS (2014) corroborate these findings - with the surveyed school heads suggesting parental affordability and lack of interest as two main determinants of student dropouts in the study sample in Pakistan.

Andrabi et al. (2013) note that in rural Pakistan the low-fee model's viability is based on keeping operational costs low and with teacher salaries usually constituting a large proportion of costs (between $80-90 \%$ ), these types of schools typically tend to employ young, educated females who are limited in terms of mobility and in terms of outside employment opportunities. The authors, using data from rural Punjab, document the existence of a 'women as teachers' supply channel - they show how the presence of a Girls Secondary School (GSS) impacts private provision, more than doubling the number of women with secondary or higher education and how the fraction of secondary educated females, in turn, has a large impact on private provision (while the fraction of similarly educated men does

7 http://tribune.com.pk/story/1070143/schools-privatisation-teachers-warn-to-resist-punjab-govt-move/ 
not). Moreover, the authors argue that whilst demand-side explanations would expect that teacher wages should then increase in GSS villages, the supply-side explanation actually suggests the opposite - the authors note that in villages where a GSS exists, private school wages are typically $27 \%$ lower. Thus, it is these lower wages that offer GSS villages a 'substantial cost advantage'. Moreover, private school wages are lower still in villages with more restricted female labour markets ( $p .3)$. This paper, therefore, provides strong evidence of the very 'tight link between the teacher labour market and educational markets in a lowincome setting...' (p. 4). It also cites the example of Alderman et al.'s (2003) study which tried to increase the supply of schools through the private educational market but which faced failure precisely because of an inability to find teachers. In this study, two pilot programmes were initiated in Balochistan, Pakistan, aimed at creating private schools for poor girls. However, whilst the pilots were relatively successful in urban areas, they failed in rural areas. One of the key reasons for this failure was the unavailability of teachers.

Thus, the low fees charged by these low-fee private schools are sustained by their reliance on low teacher salaries typically paid to young female teachers' resident in the village (more than $70 \%$ from within the village where they were born) in a patriarchal society facing limited geographical and occupational mobility (Andrabi et al. 2013, p. 5). Andrabi et al.'s (2013) paper also shows that it is typically not feasible for these types of schools to hire male teachers; they would command higher wages, and neither increasing class-sizes nor increasing fees would be a feasible option for the private schools to offset the higher male costs. In fact, doing so would result in a reduction in educational quality which would reduce the competitive advantage of the private schools as compared to the free state schooling on offer. This is also substantiated by the relatively high price elasticity based on Pakistani data which indicates that a $1 \%$ increase in prices would reduce market share per private school by $1.2 \%$ making fee hikes not feasible (Carneiro et al. 2010 cited in Andrabi et al. 2013, p. 20).

Other studies from Pakistan also discuss how 'edupreneurs' in Pakistan running low-fee private schools are limited in their ability to both expand their schools and improve educational quality due to the fact that fees are typically the only source of revenue (ILM IDEAS 2014). The business model of the 305 surveyed schools in 3 provinces in Pakistan shows that low-fee schools' financial strategy requires maintain costs below revenue levels that can be derived from the market and this, in turn, requires reducing per student costs through paying low teacher salaries (p. 29). A 'supply driven' labour market within the low-fee sector ensures low salaries and the achievement of economies of scale. The profile of teachers within this sector reflects these realities - these teachers are young females without sufficient outside opportunities. At such low wages, low-fee schools typically attract lower qualified and untrained teachers (p. 30).

Thus, keeping operational costs low by paying low salaries is an important condition for the sustainability of the low-fee school model. Using a different approach, Kingdon (2016) uses national data from India (National Sample Survey, 2014-2015) to benchmark the mean and median fee levels in private schools in different states of India. Combined with average enrolment levels (based on DISE data), the author computes the resulting average monthly revenue levels of private schools to give an idea of the maximum salary they could offer to their teachers. As an illustrative example, she notes that the average enrolment in recognised private unaided schools in Uttar Pradesh is 180 children/school and the median fee level is Rs.117/month. This would generate a mean revenue for the school of Rs.180x117= Rs.21,177 per month which would suggest they could potentially employ 5 teachers (leaving some profit for the entrepreneur and other school expenses). Thus, schools would need to keep salary costs low in order to remain operational ${ }^{8}$.

8 This paragraph is based on an email exchange with Geeta Kingdon (dated August, $9^{\text {th }}$ ), in which she shared this information on some on-going research. 
Similar findings are reported in other contexts. For example, Härmä's (2016a) study of lowfee private schools in the slums of Abuja finds that the main recurrent expenditure typically constitutes the salary bill for teaching and non-teaching staff (in the region of $73 \%$ of total costs in registered schools and $66 \%$ in unregistered schools). This not only requires a sufficient number of fee-paying pupils, but may also necessitate multi-grade teaching (to keep staff levels low in smaller schools) but also the need to pay very low salaries. Table 7 illustrates the salaries paid in low-fee private schools and shows that registered schools are typically able to pay their teachers better salaries as compared to their unregistered counterparts, and this, the author explains is linked to registered schools being able to have larger pupil numbers and being able to charge higher fees.

Table 7: Abuja, Nigeria: Full time teacher salaries, by school registration status (monthly), US\$.

\begin{tabular}{|c|r|r|r|r|r|r|r|r|}
\hline \multicolumn{4}{|c|}{ Registered schools } & \multicolumn{4}{c|}{ Unregistered schools } \\
\hline & $\begin{array}{c}\text { Mean } \\
\text { salary }\end{array}$ & $\begin{array}{c}\text { Minimum } \\
\text { salary }\end{array}$ & $\begin{array}{c}\text { Maximum } \\
\text { salary }\end{array}$ & $\begin{array}{c}\text { No. } \\
\text { cases }\end{array}$ & $\begin{array}{c}\text { Mean } \\
\text { salary }\end{array}$ & $\begin{array}{c}\text { Minimum } \\
\text { salary }\end{array}$ & $\begin{array}{c}\text { Maximum } \\
\text { salary }\end{array}$ & $\begin{array}{c}\text { No. } \\
\text { cases }\end{array}$ \\
\hline $\begin{array}{c}\text { Pre- } \\
\text { primary }\end{array}$ & 53.2 & 22.5 & 100.0 & 79 & 40.8 & 11.3 & 100.0 & 156 \\
\hline Lowest & 52.3 & 27.5 & 110.0 & 82 & 40.7 & 11.3 & 125.0 & 167 \\
\hline Middle & 64.3 & 30.0 & 135.0 & 82 & 48.6 & 11.3 & 140.0 & 167 \\
\hline Highest & 84.1 & 37.5 & 175.0 & 82 & 59.2 & 11.3 & 150.0 & 167 \\
\hline
\end{tabular}

Source: Härmä (2016a), Table 20. \$1 = 200 Naira at the time of the data collection.

Härmä (2016b) studying low-fee private schools in slums in Dar-es-Salaam, Tanzania reports similar low teacher salaries (see below). And similar findings are observed in Kampala, Uganda (Table 9).

Table 8: Dar es Salaam, Tanzania: Teacher salaries, by registration status, in low-fee private schools, per month (total teacher salary divided by 12 months), US\$

\begin{tabular}{|l|l|l|l|}
\hline & Registered & Unregistered & All schools \\
\hline $\begin{array}{l}\text { Pre-primary salary } \\
\text { level }\end{array}$ & 75.4 & 47.7 & 53.8 \\
\hline $\begin{array}{l}\text { Other education } \\
\text { levels salary }\end{array}$ & 111.7 & 91.6 & 109.3 \\
\hline
\end{tabular}

Source: Source: Härmä (2016b), Note: \$1 = TSh 2,200 at the time of the data collection. 
Table 9: Kampala, Kenya: Teacher salaries in low-fee private schools (monthly) in US\$, by registration status

\begin{tabular}{|l|c|c|c|}
\hline & $\begin{array}{l}\text { Registered } \\
\text { schools }\end{array}$ & $\begin{array}{l}\text { Unregistered } \\
\text { schools }\end{array}$ & All schools \\
\hline Average lowest salary & 51.3 & 38.9 & 48.0 \\
\hline Average median salary & 79.5 & 55.3 & 71.2 \\
\hline Average highest salary & 105.1 & 64.1 & 94.4 \\
\hline
\end{tabular}

Note: at the time of data collection in June 2016, US\$1 was equal to 3,375 Ugandan Shillings.

Source: Härmä (2016c)

Private school wages are substantially lower than wages paid to government school teachers

Härmä (2015) summarises some of the evidence on the documented low pay within the lowfee schools in various developing country contexts. In rural Uttar Pradesh, she notes that the private school teacher pay was found to be one-tenth of a government teacher's salary with government teachers typically earning in one month what a private school teacher would earn in a year (Härmä 2008 cited in Härmä 2015). Similarly, Ohara (2013) found private school teacher salaries to be one tenth, sometimes even less, than government teacher salaries in Delhi (cited in Härmä 2015). Tooley and Dixon (2005, p. 37 cited in Härmä, 2015) found private school teacher pay to be less than a third of government school teachers in Ga, Ghana; Hyderabad, India; and Lagos, Nigeria).

Andrabi et al. in the LEAPS report (2008) document extremely low salaries of private school teachers, comparable to those of unskilled workers in villages in Pakistan. In particular, they note that teachers in private schools are paid a fraction of the salary of public school teachers...' (p. 59). Even after controlling for observed differences (such as experience, gender etc.), the authors find that government school teacher salaries in rural areas of Punjab are 3-4 times as high as their private school counterparts.

Similar findings are reported by different researchers in India. Kremer \& Muralidharan (2009) using data from a nationally representative survey of rural private schools in India from 2003, notes that private school teacher salaries are a fifth of their government school counterparts (and sometimes as low as a tenth), and these low salaries enable private schools in these contexts to hire more teachers, reduce pupil-teacher ratios and reduce multi-grade teaching (p. 2). Goyal and Pandey (2009) in their study of teachers in different types of schools in Madhya Pradesh and Uttar Pradesh find that private school teacher salaries are between one-seventh and one-eighth of those of government school teachers. Muralidharan and Sundararaman (2013) further show that private school teacher salaries in their study area of Andhra Pradesh are around one eighth of regular government teacher salaries (and even lower than that of government teachers hired on short term contracts).

Kingdon (2010) also documents private school teachers' mean pay as a percentage of regular teachers' mean pay at the primary/junior school level in different parts of India in different years. This is illustrated in Table 10 below. The secular increase in regular government teachers' pay as a multiple of private pay has meant, for example, that government teacher salary as a multiple of private salary has increased steadily from about 2.5:1 in the early 1990s to as much as $12: 1$ in 2008. The author argues that these gaps would widen significantly following the Sixth Pay Commission which impacted government teacher salaries and not those in the private sector, with regular government school teachers earning significantly more than their private school counterparts, especially in low-fee schools which rely on paying low salaries to ensure they are able to charge low fees from their 
students. The author argues that following the Sixth Pay Commission, private school teachers' mean pay is likely to be around $5 \%$ that of regular government school teachers in UP, '...a truly grotesque level of inequality in teacher pay.' (p. 8). Kingdon argues that these large salary increases among regular government school teachers as compared to both their private school counterparts but also with respect to contract teachers and the average person in the population, has impacted both on the social distance between students and teachers and on the ability of the community to influence teacher accountability.

Table 10: Private unaided schools' mean monthly teacher salary as a percentage of government school teachers' mean monthly salary, different parts of India, different years.

\begin{tabular}{|c|c|c|c|c|c|c|c|c|}
\hline $\begin{array}{l}\text { School } \\
\text { level }\end{array}$ & $\begin{array}{l}\text { Kingdon's } \\
\text { study } \\
1994\end{array}$ & $\begin{array}{l}\text { Kansal's } \\
\text { study } \\
1990\end{array}$ & $\begin{array}{l}\text { Govinda/ } \\
\text { Varghese } \\
1993\end{array}$ & $\begin{array}{l}\text { Jain's } \\
\text { study } \\
1988\end{array}$ & $\begin{array}{l}\text { Bashir's } \\
\text { study } \\
1994\end{array}$ & $\begin{array}{l}\text { Singh/ } \\
\text { Sridhar } \\
2002\end{array}$ & $\begin{array}{l}\text { Murali- } \\
\text { dharan, } \\
\text { Kremer } \\
2006\end{array}$ & $\begin{array}{l}\text { Kingdon, } \\
\text { Banerji, } \\
\text { Chaudhary } \\
2008\end{array}$ \\
\hline & $\begin{array}{l}\text { Lucknow } \\
\text { City of } \\
\text { Uttar } \\
\text { Pradesh }\end{array}$ & $\begin{array}{l}\text { City of } \\
\text { New } \\
\text { Delhi }\end{array}$ & $\begin{array}{l}5 \text { districts } \\
\text { of } \\
\text { Madhya } \\
\text { Pradesh }\end{array}$ & $\begin{array}{l}\text { Baroda } \\
\text { district } \\
\text { of } \\
\text { Gujarat }\end{array}$ & $\begin{array}{l}\text { Many } \\
\text { districts } \\
\text { of Tamil } \\
\text { Nadu }\end{array}$ & $\begin{array}{l}2 \\
\text { districts } \\
\text { of Uttar } \\
\text { Pradesh }\end{array}$ & $\begin{array}{l}20 \\
\text { states of } \\
\text { India }\end{array}$ & $\begin{array}{l}11 \text { districts } \\
\text { of Bihar } \\
\text { and UP }\end{array}$ \\
\hline $\begin{array}{l}\text { Primary/ } \\
\text { junior } \\
\text { level }\end{array}$ & $\begin{array}{r}42 \\
(2.5: 1)\end{array}$ & $\begin{array}{r}39 \\
(2.5: 1)\end{array}$ & $\begin{array}{r}49 \\
(2: 1)\end{array}$ & $\begin{array}{r}47 \\
(2: 1)\end{array}$ & $\begin{array}{r}47 \\
(2: 1)\end{array}$ & $\begin{array}{r}20 \\
(5: 1)\end{array}$ & $\begin{array}{r}20 \\
(5: 1)\end{array}$ & $\begin{array}{r}8 \\
(12: 1)\end{array}$ \\
\hline
\end{tabular}

Note: In each column, the figure in parenthesis is the implied ratio of government school regular teachers' mean salary to private school teachers' mean salary. The Kingdon 1994 study sampled 182 teachers, Kansal 233 teachers, Govinda and Varghese 111 teachers, Bashir 419 teachers, Singh and Sridhar 467 teachers, and Kingdon, Banerji, Chaudhary study 734 teachers. We do not know the number of teachers sampled in Jain or Muralidharan and Kremer.

Source: Table 6.7 in Kingdon (2008), which also gives the references to the above studies.

Source: Kingdon (2010), table 2, p. 7.

Härmä (2016d) in her study of non-state provision of education in Maputo, Mozambique also finds that private school teachers are typically paid far less than their civil service counterparts. The mean salary of a private school teacher with average experience in her sample was US\$76/month which compares unfavourably with a market trader selling bread and peanuts (p.10). Private school teacher salaries also compare unfavourably with civil service teachers working at some of the sample schools - private school teachers are paid a third less than their civil service counterparts.

One of the consequences of the large salary increases among civil service teachers and the extremely low wages paid to teachers especially in low-fee private schools is the resultant discontent among those in the cadre. In India, the large economic disparity created by high government teacher salary (as a result of the 6th Pay Commission), as compared to other teachers within the education system (contract teachers, private school teachers etc.), has also led to protests as well as extreme dissatisfaction amongst this latter group particularly due to the fact that they have been shown to exhibit higher levels of effort (as proxied by lower absence rates and higher time on task) as well as better pupil outcomes (Kingdon 20109, Atherton \& Kingdon 2010). Similar discontent among the private school cadre has also been reported in newspaper accounts in Pakistan. A further harmful consequence of large civil-service rents (as compared to the private sector pay) is that a market can emerge for these jobs where politicians appoint candidates willing to pay for coveted teacher positions and these teachers are likely to exert less effort having paid for their jobs rather than being competitively selected into them (Muralidharan and Sundararaman, 2013).

9 http://ceid.educ.cam.ac.uk/publications/WP29 GK SixthPay.pdf 
Low fee private schools pay a market clearing wage which is typically below mandated minimum wages but which is competitive

According to Kingdon (2010), private schools typically do not comply with governmentmandated minimum wages and instead pay market-clearing wages that are determined by existing demand and supply of teachers (p. 8). In India, for example, the very high levels of unemployment of educated persons within the country $(11.7 \%$ in rural India and $10.1 \%$ in urban India, individuals with undergraduate degrees) means the existence of an excess supply of workers with private schools (like any other private enterprise) taking advantage of this to pay market-clearing wages. According to Kingdon, this is especially true at the primary level where the skills of the individuals are typically viewed to suffice in teaching children at this level. Andrabi et al. (2013) also argue that the potential pool of educated teachers is limited in Pakistan and in other developing countries - in sub-Saharan Africa, for example, less than $12 \%$ of the population complete secondary schooling and even fewer do so in rural areas (p. 2).

Evidence from other regions also suggests that LFPS typically tend to pay wages well below the legal minimum wage. For example, in Lagos and Kwara States (Nigeria), teacher salaries in all the low-fee schools studied were found to be significantly below the mandated minimum wage. There were clear differences between different types of low-fee schools - registered LFPS were found to pay 1.5 times as much as un-registered schools in both locations (Härmä 2011a and Härmä 2011b cited in Härmä, 2015). Härmä (2011d) notes that in Lagos, the mean private school salary was $60 \%$ of minimum wage and about $42 \%$ of the starting salary of a government school teacher (Härmä, 2015, p. 183). However, several researchers studying low fee schools across various contexts have noted that private schools typically offer low but market-competitive wage rates.

Private schools are able to offer a low salary to their employees because they can tap into specific demographic groups (unemployed educated youth, secondary educated women with limited geographical and occupational mobility and other cultural constraints) who are typically less qualified and have less experience than their government school counterparts. ILM IDEAS (2014) also reports that teachers in the low-fee sector earn wages 'well below equivalent salaries in the state school sector and below the minimum wage level of PKR 9000 in Punjab.' (p. 30). However, the pool of educated unemployed rural secondary school and college graduates from which low-fee private schools typically hire appears to be large enough to ensure that the labour supply of such teachers is fairly elastic (Kingdon and Sipahimalani-Rao, 2010 cited in Muralidharan and Sundararaman, 2013).

Whilst some of the substantial wage premium that government school teachers earn over and above the market clearing wage offered to private teachers is explained by their better education and outside opportunities, and partly by a compensating differential to locate in rural and remote areas, but mainly represents a union and civil service premium (Muralidharan and Sundararaman, 2013). In discussing contract government teachers within their study, the authors note that rather than being 'exploitative', contract teachers' employment terms are actually in line with the market clearing wage paid by the private sector and whilst these low wages may seem exploitative, in reality the distortion is not the low salaries of contract (and private school teachers) but the above-market wages of civil service teachers who are shown to produce the same or worse outcomes among children at significantly higher costs.

\section{Teachers in the low-fee sector lack motivation and commitment}

Teacher satisfaction and morale are documented to be low within the low-fee sector. This is unsurprising given that these teachers are typically unqualified, untrained and poorly paid with little or no benefits and job security and very low career progression prospects (Adelabu 
and Rose 2004; Härmä 2008; Härmä and Adefisayo 2013 cited in Härmä 2016c). As already mentioned, in Pakistan, the pre-existing wage differentials between men and women as well the latter's occupational and geographical immobility are capitalised upon to populate low-fee schools with female teachers. However, a recent study from rural Punjab clearly documents the relatively lower performance of female teachers (across both government and private school samples) with one explanation being the lack of motivation and commitment of female teachers in general as compared to their male counterparts (Marine 2015). The author notes that $27 \%$ of the female teachers (as opposed to $16 \%$ male teachers) in his sample declared that they would stop teaching once they got married and $47 \%$ females stating they would stop depending on their spouses' decision as opposed to only $3 \%$ males. Alternatively, the author proposes that female teachers' responsibilities at home may also influence their motivation and effort at work - with female teachers in the sample spending on average 5 hours doing house work as opposed to the 3 hours spent by their male counterparts. This also links in with the low status awarded to the teaching profession in the country with teaching often perceived as the last choice among young professionals (UNESCO 2013 and Westbrook et al. 2009 cited in Marine 2015).

Whilst the business model of low-fee schools necessitates paying low salaries to staff, one of the consequences of this is that the resultant threat of loss of employment for teachers may be less worrying than if pay were higher. Additionally, in rural areas, the pool of entrants is so limited that dismissal may be less likely due to the difficulty of finding a replacement (Härmä, 2016e). This might, in turn, impact effort and incentives within the school.

The LEAPS (2008) study illustrates that turnover among teachers in the private sector is high $-25 \%$ of the teachers are replace every year and whilst '...this frequent turnover may hurt the private sector...it also allows constant replenishment of the teaching workforce and pruning of non-performing teachers' (p. 59). However, evidence from the ILM IDEAS (2014) study does not suggest that the low salaries paid to teachers within the low-fee sector had any negative impact on staff turnover. According to the study, one of the interviewed school heads noted that neighbouring schools offered even lower salaries than his school (as low as Rs.1500/month). Thus, the outside options available to teachers within these schools are limited and the alternative for many would require them to leave the community to search for work or to remain within the home. Poor labour relations, therefore, do not seem to feature within the functioning of the low-fee model (p. 30). Nevertheless, the same study notes that the average tenure of a teacher within a low-fee school is typically 1-3 years (at the middle and secondary level) with teachers at the primary level having a substantially greater turnover than those teaching at higher levels. More specifically, the study finds that within primary schools, very few teachers leave in the first few months but $19 \%$ tend to leave within one academic year. The study suggests that within these low-fee schools, teachers at the primary level are mostly young women who use teaching as a 'short-term job opportunity before returning to studies or getting married.' (p. 31).

Similar findings, of teachers in low-fee schools using teaching as a 'time pass' have been cited from contexts such as India with 'ambivalent' teacher attitudes with teachers suggesting that whilst their private sector jobs were good enough for the moment, they aspired to better paying government jobs with 'not having to do any work' in cushy government jobs cited as an important attraction within the sector (Härmä, 2015). Within the ILM IDEAS study, teachers typically tended to cite attractive employment opportunities and higher salaries as reasons for arriving and leaving the workforce. Focus group discussions within the study also revealed that sometimes teacher training is used as a non-financial compensation for teaching staff although this tends to be confined to those teaching at higher education levels and to those who are already experienced teachers (p. 31). Moreover, there are limited incentives for private schools to train teachers. As Andrabi et al. (2015) note, better teachers in private schools move to schools that reward them more and this is '...consistent with the idea that the schooling market works by allocating scarce, productive teachers across vertically-differentiated schools... and that high value-added teachers exit low quality schools 
faster, as do low value-added teachers in high quality schools. The high turnover and attrition could, in turn, create problems in the labor market as it sharply reduces the incentive for school owners to train teachers. Particularly in low quality schools, owners will realize that more training will make it more likely that they will lose their teachers to higher quality schools. The gains to training will be realized by the schools that the teachers eventually move to rather than the schools that trained them. This in turn suggests experiments where such training is subsidized by the government.' (p. 106).

5. Is a minimum wage for teachers feasible and appropriate in Pakistan?

\section{Current wage policy in Pakistan is not efficient}

There is now sufficient evidence worldwide to showcase the importance of teacher quality in determining student learning. Evidence from Pakistan (and other parts of the world) has consistently shown that some characteristics of teachers are especially important in determining student learning - teachers with temporary contracts appear to perform better than those on permanent ones and locally recruited teachers may be more effective (Marine, 2015), and how a teacher teaches within a classroom is a critical determinant of student learning whilst standard resume characteristics appear to have no relationship with student outcomes (Aslam \& Kingdon 2011). However, previous evidence has also convincingly shown that teachers in the public sector are typically rewarded for resume characteristics (such as qualifications, experience and tenure) that are not directly linked to student outcomes (Aslam and Kingdon, 2011). This study from Pakistan highlights the inefficient nature particularly of government teacher wage schedules where teachers are typically rewarded based on fixed rules rather than based on their performance. In some respects, the authors find that private school wage schedules are relatively more efficient and flexible though in some instances private schools also reward their teachers based on observable characteristics (which are shown not to directly impact student learning) perhaps to signal to prospective parents that they have qualified staff despite the fact that qualifications do not necessarily improve staff productivity.

Marine (2015) also argues that data on both government and private schools in rural Punjab indicates that the 'current wage policy is...far from being the most efficient' (p.35). In particular, the author argues that in their data both government and private school teacher wages are determined by gender and by qualifications. Female teachers are typically paid less in their sample and this is partly due to the lack of outside options. The rewards to training appear large in the public sector while the private sector appears to reward experience. Teachers on permanent contracts are also paid more in public schools although this is not the case in private schools. In both school types, local teachers are paid less and this difference is higher in private schools. One explanation put forward by the author for this finding is that locally resident teachers value convenience and safety and have lower travel costs and are thus willing to accept lower wages. However, similar to the findings by Aslam and Kingdon (2011), the author notes that these criteria determining wages do not necessarily determine teacher quality. Hence, there are glaring inefficiencies in the wage schedules across the two sectors, but perhaps more so in the government sector than in the private one. Nevertheless, teacher wage policy could be a useful tool for policy makers to improve school quality as these policies are easier to implement than those aimed at raising teacher education and experience. In particular, there is typically no system of rewarding teacher performance through higher wages.

\section{Rewards and penalties in the private sector are different than the public sector}

Broadly speaking, the private sector is far more flexible and tends to link pay with performance as compared to the government sector, which typically rewards inputs. The LEAPS study (Andrabi et al. 2008) shows that better paid teachers in low-fee private schools 
are associated with higher student scores. Moreover, the reward and penalty structures facing teachers across the two sectors are also different with private sector compensation schemes rewarding teachers more for effort and performance as well as to outside opportunities (those who are likely to be paid more outside the teaching sector are also paid higher salaries as teachers). Moreover, once they are hired, teachers in private schools face stringent accountability measures and credible threats to dismissal, unlike their government school counterparts who have 'jobs for life' and who are virtually unsackable.

A more recent study in Pakistan based on the LEAPS data set by Bau and Das (2016) illustrates that decreasing public sector wages by as much as third does not significantly affect the pool of job-seekers suggesting that '...the outside option is never more attractive than the public sector, even after the wage decline.' (p. 5). Using this rich data set, the authors arrive at three main conclusions:

1) Teacher quality matters for student outcomes within the Pakistani context as much as it does in OECD countries.

2) Observed teacher characteristics are linked to teacher compensation but explain no more than $5 \%$ of the variation in teacher value added.

3 ) There is no correlation observed between teacher value added and wages in the public sector with a policy change used by the authors (public sector hiring shifted from permanent to temporary contracts reducing wages by 35\%) having no negative impact on teacher value added in the short term or in the longer term (after 4 years). Thus, the $500 \%$ differential in teacher wages between private and public sector workers observed within their sample is indicative of highly inefficient wage schedules that prevail within the public sector in Pakistan.

Importantly, the authors suggest that reducing public sector wages is unlikely to impact either the pool of entrants or teacher value added in terms of student outcomes. However, the authors caution that whilst the natural experiment used in this analysis mimics a wholesale reduction in wages, the policy change combined changes in remuneration as well as returns to effort (permanent versus temporary contracts) and therefore, the authors are unable to distinguish between these two potential effects. Therefore, the results are actually showing that 'temporary contracts induce a combination of teacher effort and quality that can yield the same learning at half the cost.' (p. 7). In a companion paper, Bau and Das (2014 cited in Andrabi et al. 2015) compute the productivity of teachers in the private sector using LEAPS data over 4 years and show that unlike in the public sector, there is a strong correlation between teacher wages and teacher value-added in private schools. The authors suggest that this correlation exists because better teachers move to schools that reward them better (with no variation in wages apparent by teacher value-added within the same school).

\section{Laissez Faire? Let the market do its job?}

This rapid review of evidence has shown that the dynamics facing the private sector, and in particular the low-fee sector, are very different from those facing the government sector (or even elite private schools). In particular, teachers salaries in the government sector are high and the wage schedules particularly inefficient (with teachers rewarded for possessing observable characteristics that have been shown in the literature to be linked to student outcomes) and are often determined more by the bargaining power of strong teacher unions and associations and pre-determined wage scales than by productivity (Aslam et al. 2016). Teacher salaries in the private sector and especially the low-fee sector, on the other hand, are often significantly lower. These salaries are often below the minimum wage but are competitive, market-clearing wages. Unlike public sector wages that are determined through fixed criteria and do not respond to outside conditions, wages within the private sector and especially within the low-fee sector are responsive to market conditions.

Opinion, however, is ideologically divided; is it fair for private schools to 'exploit' (often) young women with limited outside options and occupational and geographical immobility? Or are 
these private schools offering employment opportunities and hence empowering these young women who are limited by alternative outside opportunities? This question does not have a simple answer. To come close to answering it, however, we must ask:

1) What is the intention of a minimum wage legislation policy especially within the context of teachers?

2) What are the realities of a low-fee or budget private school?

3) And finally, to what extent can we expect any policy to be actually implemented within a diverse and highly heterogeneous private sector?

With respect to the first, as a wage policy, a minimum wage intends to set a legal minimum pay threshold to guarantee a given wage to all employees. However, even as a wellintentioned employment policy, it may not have the desired textbook consequences. For example, a minimum wage, by interfering with the normal workings of the market, may induce unemployment or cost-push inflation or may increase the number of workers working in the 'black market' and may not benefit the poorest. In the context of teachers, and when an employment policy is used as an 'education policy', many would agree that public school teachers already earn substantially more not only than their private school counterparts but also compared to average individuals in the country at least in South Asia. Any attempt by the government to reduce their salaries is likely to be met by intense resistance through union pressure and militant activities (Kingdon and Muzammil 2009). This leaves teachers in the private sector at large. As already mentioned, the private sector is not a homogenous entity in Pakistan (or in other parts of the world). Whilst a minimum wage policy may not work to the detriment of a recognised, elite, private school located in an urban area, it may have severe implications on the viability of a low-fee private school.

As already mentioned, the business model of low-fee schools relies extensively on paying low salaries to teachers which are then passed on to students in the form of low fees. The reality of a low-fee private school is very different from that of an elite private school or a larger urban or semi-urban school. A lack of resources (and the resultant viability of the business model) is one of the main reasons why budget schools cannot hire teachers at higher salaries. Indeed, a recent study in Punjab, India, by the Centre for Civil Society (2014), suggests that school owners in such low-fee establishments are in 'constant worry' following the RTE Act (2009) in India which mandates every private school to follow specific 'inputcentric' norms and standards to obtain recognition. In particular, the school owners in budget schools cannot hire teachers at par with high fee charging schools or government schools. In their study, the authors of this report found that the average monthly salary of a teacher in a 'budget private school' was Rs 1925 in Punjab. However, there is a 'resident fear' among school owners that the $6^{\text {th }}$ Pay Commission may act as the benchmark for deciding minimum teacher salaries (p. 6). According to this report, this has resulted in many such schools either shutting down or fearing shutting down as they are unlikely to be able to comply with such stringent norms if they are enforced. Other researchers (see Kingdon's opinion pieces for example ${ }^{10}$ ) have also argued that many of these infeasible norms and standards set out in the RTE Act have resulted in large-scale low-fee private school closures, have reduced the existing education standards within India and have '...raided the autonomy of private schools (by foisting) the same ruinous official/political interference on private schools that has been so injurious to the running of government schools.'

Thus, even well-intentioned government policies can inadvertently result in low-fee private school closures by directly impinging on the functioning of fee-charging providers. The unintended consequences of an ill-thought out legislation can have far-reaching impacts on the education system in Pakistan. Evidence from around the world now shows that, overall, private schools are accessed by large proportions of children and are able to provide learning

10 http://blogs.timesofindia.indiatimes.com/toi-edit-page/schooling-without-learning-how-the-rte-actdestroys-private-schools-and-destroys-standards-in-public-schools/ 
outcomes that are at least at par with those provided by the state sector, albeit at a significantly lower per pupil cost (see for instance Day Ashely et al. 2014). Thus, any policy or legislation that is likely to impact millions of children needs to be carefully thought through. One possible solution is to consider a minimum wage based on the size of the low-fee school, for example exempt all schools employing less than a given number of individuals. However, careful consideration needs to be made before mandating such a policy.

It is also important to consider another vital aspect - to what extent can we expect such a policy to be actually implemented within the private sector? This relates to existing concerns of the ability of the government to regulate the private sector. Many private schools operate 'blow the radar' and within the extra-legal sector (unrecognised and unregistered schools, see for instance Dixon (2012). There is no understanding of the scale of these schools in many contexts, including Pakistan, let alone the government being able to implement or enforce any policies on them. Additionally, there are those schools that may have gained recognition from the government and supposedly abide by the regulations of recognition but researchers report unofficial payments and bribes as being rampant within these settings regardless of the school meeting mandated government criteria or not (Dixon and Tooley, 2005 cited in Dixon 2012). Adding an additional policy through a minimum wage in such an environment is unlikely to meet the intended outcome; if anything it may add additional burdens on already struggling school proprietors to make unofficial payments to government officials in charge of enforcing regulations and thus expose them to further corruption and illegality.

\section{Bibliography}

Adelabu, M., and P. Rose. (2004), 'Non-State Provision of Basic Education in Nigeria.' In Nigeria: Study of Non-State Providers of Basic Services, edited by G. Larbi, M. Adelabu, P. Rose, D. Jawara, O. Nwaorgu, and S. Vyas, 41-72. Birmingham: International Development Department, University of Birmingham.

Alderman, H., Orazem, P.F. and E.M. Paterno (2001), 'School Quality, School Cost and the Public/Private School Choices of Low-Income Households in Pakistan', Journal of Human Resources, 36(2):304-326.

Alderman, H., Kim, J. \& P. F. Orazem (2003), 'Design, Evaluation and Sustainability of Private Schools for the Poor: The Pakistan Urban and Rural Fellowship School Experiments', Economics of Education Review, 22 (3): 265-274.

Alif Ailaan (2015), Rashid, Ammar, and Mosharraf Zaidi. Reclaiming Dignity: The State of Teachers' Unions and Their Future. Rep. Islamabad: Alif Ailaan, 2015.

Andrabi, T., Das, J., and Khwaja, A. I. (2008). A dime a day: the possibilities and limits of private schooling in pakistan. Comparative Education Review, 52(3).

Andrabi T, Das J, Khwaja Al (2013) Students today, teachers tomorrow: identifying constraints on the provision of education. Journal of Public Economics100: 1-14.

Andrabi. T., Das, J. \& A. I. Khwaja (2015), 'Delivering education: a pragmatic framework for improving education in low-income countries', In: Handbook of International Development and Education, edited by Pauline Dixon, Steve Humble \& Chris Counihan.Elgar.

ASER India (several years) Annual status of education report (rural) 2012. New Delhi: ASER Centre.

ASER Pakistan (several years) Annual status of education report: ASER-Pakistan 2013 National. Lahore: South Asian Forum for Education Development. 
Aslam, M. (2009), 'The relative effectiveness of government and private schools in Pakistan: are girls worse off?' Education Economics, 17 (3): pp. 329-354.

Aslam, M. \& G. Kingdon (2009), 'Public-private sector segmentation in the Pakistani labour market', Journal of Asian Economics, 20:34-49.

Aslam M, Kingdon G (2011) What can teachers do to raise pupil achievement? Economics of Education Review 30(3): 559-574.

Aslam, M. \& S. Rawal (2015), 'Teachers - an indispensable asset', In: Handbook of International Development and Education, edited by Pauline Dixon, Steve Humble \& Chris Counihan.Elgar.

Aslam,M. Rawal, S. and G. Kingdon (2014), 'Teacher Quality', Background paper for Student Learning in South Asia: Challenges, Opportunities and Policy Priorities (Halil Dundar, Tara Beteille, Michelle Riboud and Anil Deolalikar), The World Bank, Washington DC.

Aslam, M., Rawal, S., Asadullah, N., Bari, F., Kingdon, G., Malik, R. \& P. Rose (2016), 'Teacher Politics: Meeting Educational Quality Challenges with Teachers', Report prepared for the Education Commission, September 2016.

Atherton, P. \& Kingdon, G. (2010), 'The relative effectiveness and costs of contract and regular teachers in India', CSAE WPS 2010-15.

Aziz, M., Bloom, D.E., Humair, S., Jimenez, E., Rosenberg, L. \& Z. Sathar (2014), 'Education system reform in Pakistan: why, when and how? IZA Policy Paper 76, Bonn, Germany.

Bau, N and J. Das (2016), 'The Misallocation of Pay and Productivity in the Public Sector: Evidence from the Labor Market for Teachers', May 2016.

Bau, N. \& J. Das (2014), 'The Allocation of Pay and Productivity in the Public Sector: Evidence from the Labor Market for Teachers', Washington DC., in process.

Carneiro, P. Das, J. and H. Reis (2016), 'The Value of Private Schools: Evidence from Pakistan', Centre for micro data methods and practice, cemmap working paper CWP 22/16 and The Institute of Fiscal Studies \& Department of Economics, UCL.

Centre for Civil Society (2014),'Limiting Choices and Denying Opportunities! The Case of School Closures in Punjab', Centre for Civil Society, India.

Day Ashley L, Mcloughlin C, Aslam M, Engel J, Wales J, Rawal S, Batley R, Kingdon G, Nicolai S, Rose P (2014) The role and impact of private schools in developing countries: a rigorous review of the evidence. Final report. Education Rigorous Literature Review. Department for International Development.

Dixon, P. (2012). Why the denial? low-cost private schools in developing countries and their contributions to education. Econ Journal Watch, 9(3):186\{209.

Dundar, H.,T. Béteille, M. Riboud, and A. Deolalikar. (2014), Student Learning in South Asia: Challenges, Opportunities, and Policy Priorities. Directions in Development. Washington, DC: World Bank. 
Fennell, S. (2013), 'Low-fee private schools in Pakistan: a blessing or a bane? In Srivastava, P. (ed.) Low-Fee Private Schooling: Aggravating Equity or Mitigating Disadvantage? Oxford Symposium Books, pp. 65-82.

Goyal S, Pandey P (2009) How do government and private schools differ? Findings from two large Indian states. Washington, DC: World Bank.

Härmä J. (2008), 'Are low-fee private primary schools in rural Uttar Pradesh, India, serving the needs of the poor? Unpublished doctoral thesis, Brighton, University of Sussex.

Härmä J. (2011a), 'Study of Private Schools in Kwara State', DFID Education Sector Support Programme in Nigeria, Report KW326.

Härmä J. (2011b), 'Study of Private Schools in Lagos State', DFID Education Sector Support Programme in Nigeria, Report LG303.

Härmä, J., and F. Adefisayo. (2013), 'Scaling Up: Challenges Facing Low-fee Private Schools in the Slums of Lagos, Nigeria.' In Low-fee Private Schooling: Aggravating Equity or Mediating Disadvantage?, edited by P. Srivastava, 129-152. Oxford: Symposium Books

Härmä J. (2015), 'Private schooling and development: an overview', In: Handbook of International Development and Education, edited by Pauline Dixon, Steve Humble \& Chris Counihan.Elgar.

Härmä J. (2016a), Study of low-fee private schools in the slums of Abuja, Nigeria, Market research study report, prepared for Capital Plus Exchange.

Härmä J. (2016b), Study of low-fee private schools in the slums of Dar es Salaam, Tanzania, Market research study report, prepared for Capital Plus Exchange.

Härmä J. (2016c), Study of low-fee private schools in the slums of Kampala, Kenya, Market research study report, prepared for Capital Plus Exchange.

Härmä J. (2016d), 'Is there a private schooling market in poor neighbourhoods in Maputo, Mozambique? Exploring the role of the non-state education sector', Oxford Review of Education.

Härmä J. (2016e), 'School choice in rural Nigeria? The limits of low-fee private schooling in Kwara State', Comparative Education, 52 (2): pp. 246-266.

ILM IDEAS (2014), 'Access to Finance for Low Cost Private Schools in Pakistan', ILM IDEAS \& DFID.

ISAPS (2010), Private Sector Education in Pakistan: Mapping and Musing, Institute of Social and Policy Sciences, Islamabad, Pakistan (with the support of DFID).

Jain, P. S and R. H. Dholakia (2009), 'Feasibility of Implementation of Right to Education Act', Economic \& Political Weekly, 44(25): 38-43.

Kingdon, G. and V. Sipahimalani-Rao (2010), 'Para-Teachers in India: Status and Impact,' Economic and Political Weekly, XLV, 59-67.

Kingdon, G. \& Muzammil, M. (2009) "A political economy of education in India: The case of Uttar Pradesh”, Oxford Development Studies, 37, No. 2: 123-144, June. 
Kingdon, G. (2010), 'Impact of the Sixth Pay Commission on Teacher Salaries: Equity and Efficiency Effects', RECOUP Working Paper No. 29. Research Consortium on Educational Outcomes and Poverty.

Kingdon, G. (2016), 'The extent of private schooling in India and its costs', Mimeo (June 2016).

Kremer M, Muralidharan K (2008) Public and private schools in rural India. In: Peterson P, Chakrabarti R (eds) School choice international. Cambridge, MA: MIT Press.

LEAPS report (2008), 'Learning and Educational Achievements in Punjab Schools', Pakistan.

Marine, De. Talance' (2015), 'Better Teachers, Better Results'? Document de travail, DT/2015-21. Dauphine Universite' Paris.

Mc Loughlin, C. (2013), 'Low-cost private schools: evidence, approaches and emerging issues', EPS-PEAKS, DFID, University of Birmingham.

Mingat, A. (2002) Teacher Salary Issues in African Countries. Processed, Africa Region, Human Development Analysis and Policy Development Support Team, World Bank, Washington, DC.

Muralidharan, K. \& V. Sundararaman (2013), 'Contract Teachers: Experimental Evidence from India'. UC San Diego and NBER, BREAD and JPAL.

Ohara $Y$ (2013), 'The regulation of unrecognised low-fee private schools in Delhi: potential implications for India's Right to Education Act.', In: Srivastava P (ed.) Low-fee private schooling: aggravating equity or mitigating disadvantage? Oxford: Symposium.

Rawal, S. \& G. Kingdon (2010), 'Akin to my teacher: does caste, religious or gender distance between student and teacher matter? Some evidence from India', DoQSS Working Paper 1018. London: Department of Quantitative Social Science Institute of Education, University of London

Schirmer, S. (2010), ' Hidden Assets: South Africa's Low-fee Private Schools. ' Centre for Development and Enterprise, In Depth No.10.

Srivastava, P. (2006), 'Private Schooling and Mental Models About Girls' Schooling in India.' Compare 36 (4): 497-514.

Srivastava, P. (2013), 'Low-fee private schooling: issues and evidence', In: Low-fee Private Schooling: Aggravating Equity or Mediating Disadvantage?, edited by P. Srivastava, 129152. Oxford: Symposium Books

Srivastava, P., Noronha, C. \& S. Fennell (2013), 'Private sector research study: Sarva Shiksha Abhiyan', DFID India.

Tooley, J. \& P. Dixon (2005), Private Schooling is Good for the Poor, Washington DC, the Cato Institute.

UNESCO (2013). Status of teachers in Pakistan. Technical report, UNESCO and ITA.

Westbrook, J., Shah, N., Durrani, N., Tikly, C., Khan, W., and Dunne, M. (2009). Becoming a teacher: Transitions from training to the classroom in the nwfp, Pakistan. International Journal of Educational Development, 29(4):437\{444. 


\section{Additional information}

\section{Author}

This query response was prepared by Monazza Aslam

\section{Contributors}

Geeta Kingdon, Institute of Education

Prachi Srivastava, University of Sussex

Joanna Härmä, University of Sussex

Claire Mc Louglin, University of Birmingham

Moses Oketch, Institute of Education

Mo Adefeso, The Education Partnership Centre

About Helpdesk reports: The HEART Helpdesk is funded by the DFID Human Development Group. Helpdesk reports are based on 5 days of desk-based research per query and are designed to provide a brief overview of the key issues, and a summary of some of the best literature available. Experts may be contacted during the course of the research, and those able to provide input within the short time-frame are acknowledged.

For any further request or enquiry, contact info@heart-resources.org

HEART Helpdesk reports are published online at www.heart-resources.org

\section{Disclaimer}

The Health \& Education Advice \& Resource Team (HEART) provides technical assistance and knowledge services to the British Government's Department for International Development (DFID) and its partners in support of pro-poor programmes in education, health and nutrition. The HEART services are provided by a consortium of leading organisations in international development, health and education: Oxford Policy Management, CfBT, HERA, the Institute of Development Studies, the Liverpool School of Tropical Medicine and the Nuffield Centre for International Health and Development at the University of Leeds. HEART cannot be held responsible for errors or any consequences arising from the use of information contained in this report. Any views and opinions expressed do not necessarily reflect those of DFID, HEART or any other contributing organisation. 